\title{
Stigmasterol and $\beta$-Sitosterol: Antimicrobial Compounds in the Leaves of Icacina trichantha identified by GC-MS
}

Taye Temitope Alawode ${ }^{1 *} \mathbb{D}$, Labunmi Lajide ${ }^{2}$, Mary Olaleye ${ }^{3}$ and Bodunde Owolabi ${ }^{2}$

\begin{abstract}
Background: The development of resistance to many antibiotics currently in use has necessitated the search for more effective alternatives. Plants have been used in ethnomedicine in different parts of the world to treat various diseases. Many studies on plants have confirmed their medicinal potentials and have led to the isolation and characterization of several potential drug candidates. This study investigates the leaves of Icacina trichantha for antimicrobial properties and seeks to identify the compounds responsible for the observed activities. The leaves of Icacina trichantha are used in ethnomedicine for the treatment of skin infections. In this study, a solvent-based fractionation of bioactive compounds in the leaves of Icacina trichantha was carried out using hexane, ethyl acetate, and methanol. The resultant extracts were screened for antimicrobial activity against six bacteria and four fungi using standard procedures. GC-MS analysis of the most active fraction was carried out.

Results: The non-polar fraction (hexane) showed better antimicrobial activity than the ethyl acetate and methanol extracts. At $200 \mathrm{mg} / \mathrm{mL}$, the fraction showed inhibition of $28.0 \pm 0.82,23.7 \pm 0.47$, and $24.6 \pm 0.94$ against Staphylococcus aureus, Escherichia coli, and Bacillus subtilis, respectively. At the same concentration, the extract showed zones of inhibition of $18.0 \pm 0.82$ against Candida albicans and Penicillium notatum. The lowest Minimum Inhibitory Concentrations (MIC) values of $2.5 \mathrm{mg} / \mathrm{mL}$ were obtained against Staphylococcus aureus, Escherichia coli, and Bacillus subtilis. GCMS analysis of the hexane extract revealed 62 peaks, out of which ten peaks were successfully characterized.

Conclusions: None of the extracts screened for antibacterial and antifungal activities in this study is as potent as the standard drugs, Gentamicin and Tioconazole. The hexane extract, however, showed some activity against the microorganisms and was analyzed using GC-MS. The hexane extract contained many bioactive compounds, some of which could not be identified. Two of the identified compounds, Stigmasterol and $\beta$-Sitosterol, are known to possess antimicrobial properties. However, the unidentified compounds could also have contributed significantly to the antimicrobial activities of the extract.
\end{abstract}

Keywords: Icacina trichantha, Hexane fraction, GC-MS, Antimicrobial, Stigmasterol, $\beta$-Sitosterol

\section{Background}

Treating microbial infections, especially in immunosuppressed patients, is still a severe challenge because microorganisms have developed resistance to many

\footnotetext{
*Correspondence: onatop2003@yahoo.com

${ }^{1}$ Department of Chemistry, Federal University Otuoke, Otuoke, Bayelsa State, Nigeria

Full list of author information is available at the end of the article
}

antibiotics available in the market [1]. Drug resistance arose from the misuse of the existing antibiotics. Up to one-half of deaths in developing countries are due to infectious diseases [2]. The unavailability of an adequate antibiotic pipeline has resulted in the emergence of many types of infections that are very difficult to treat, owing to the paucity of viable alternative antibiotic alternatives [3]. Plants produce a wide variety of phytochemicals produced as part of their 
survival strategies against predation by microorganisms, insects, and herbivores [4]. These compounds are potential alternatives to the current antibiotics. The skeletons of these compounds vary and belong to various classes (flavonoids, tannins, alkaloids, and steroids, among others). The World Health Organization recognizes medicinal plants as one of the sources of new drug varieties [5].

Plants are in many parts of the world, used as medicines to treat diseases by traditional healers. Several studies have established the potency of several of these plants, and further studies have been carried out on many to identify the compounds responsible for the observed activities. Icacina trichantha Oliv. (Icacinaceae) is used by herbalists in southwestern Nigeria for the treatment of skin infections. Icacina trichantha is a shrub (with large tuber) regarded as a weed of field crops that grows up to $2 \mathrm{~m}$ in height. The tuber extracts of the plant possess antioxidant, analgesic, anti-inflammatory, anti-convulsive, sedative, antimicrobial, and antidiabetic activities [6-9]. The cytotoxic diterpenoids-icacenone, icacinol, 17-hydroxyicacinol, humirianthol, and humirianthenolide $\mathrm{C}$ have been reported in the tuber of the plant [10]. Phytochemical screening of the hexane, ethylacetate, and ethanol extracts of the leaves indicate the presence of different secondary metabolites including tannins, phenols, terpenoids, glycosides, steroids, and flavonoid $[6,11]$.

Some reports exist in the literature on the antimicrobial properties and GCMS analysis of different extracts of the leaves of I. trichantha. For example, a previous study carried out antimicrobial studies and GCMS analysis on hexane, ethylacetate, and ethanol leaf extracts of the plant. The results indicated that the leaves possess antibacterial activity against Escherichia coli, Pseudomonas aeruginosa and Klebsiella oxytoca [11]. In the current study, we have screened hexane, ethylacetate, and methanol leaf extracts for activity against a broader range of microorganisms-six bacteria and four fungi. In addition, GCMS analysis, as used in the current study, is bioactivity guided. GCMS analysis was carried out on only the extract demonstrating the best antimicrobial activity to identify the compounds likely responsible for the antimicrobial activities displayed by the plant. Two other studies $[6,12]$ screened aqueous and methanol/ethanol extracts of the leaves of the plant for antimicrobial activity against a broad range of microorganisms. While some of these organisms have also been used in the current study, we have adopted a completely different extraction protocol. We have compared the results obtained in this study with those previously reported in the literature.

\section{Methods}

\subsection{Sample collection, preparation, and extraction}

The samples used in this study (the leaves of I. thricantha) were collected from the Botanical Gardens, University of Ibadan, Nigeria. The samples were air-dried and ground. After grinding, a $1 \mathrm{~kg}$ portion was subjected to extraction using $2.5 \mathrm{~L}$ of hexane, ethyl acetate, and methanol sequentially. The extracts obtained were concentrated to dryness using a rotary evaporator.

\subsection{Antimicrobial assay on extracts \\ 2.2.1 Preparation of isolates}

Extracts were screened for activities against Staphylococcus aureus, Bacillus subtilis, Salmonella typhi, Pseudomonas aeruginosa, Escherichia coli, Klebsiella pneumoniae, Rhizopus stolonifer, Aspergillus niger, Candida albicans, and Penicillium notatum. All the microorganisms are clinical isolates obtained from the laboratory of the Department of Pharmaceutical Microbiology, University of Ibadan, Nigeria. From the stock of each organism, an entire loop was taken, inoculated into $5 \mathrm{~mL}$ sterile nutrient broth and subsequently incubated for $18-24 \mathrm{~h}$ at $37^{\circ} \mathrm{C}$. A $1: 100\left(10^{-2}\right)$ dilution of each organism was then prepared by introducing $0.1 \mathrm{~mL}$ of the organism into $9.9 \mathrm{~mL}$ of sterile distilled water [13].

\subsubsection{Antibacterial assay (agar-well diffusion method)}

Prepared sterile nutrient agar (containing $0.2 \mathrm{~mL}$ of each of the diluted organisms) at $45{ }^{\circ} \mathrm{C}$ was poured aseptically into sterile Petri dishes and allowed to solidify for about 40-45 min. Wells were made in the solidified nutrient agar using a standard $8 \mathrm{~mm}$ cork borer. The number of wells made is equivalent to the concentrations of each of the extracts. Serial two-fold dilution of each extract was prepared in the current study in a concentration ranging from 6.25 to $200 \mathrm{mg} / \mathrm{mL}$. The extracts $(100 \mu \mathrm{L})$ were then introduced into the wells. The plates were left on the bench for $45 \mathrm{~min}$ before being incubated for between $18-24 \mathrm{~h}$ at $37^{\circ} \mathrm{C}$ (to allow pre-diffusion). The standard drug, Gentamicin, was used as the control [13]. The study was carried out in triplicates.

\subsubsection{Antifungal assay (agar diffusion-surface plate method)}

The study was carried out in triplicates. Sabouraud Dextrose Agar (62 g/L) was poured aseptically into sterile plates and allowed to solidify. A sterile spreader was then used to cover the surface of the agar with $0.2 \mathrm{~mL}$ of the organism (at $10^{-2}$ dilution). An $8 \mathrm{~mm}$ standard, sterile cork borer was then employed in making wells on the plates. A $100 \mu \mathrm{L}$ portion of the 
extracts (at different concentrations) and the control (Tioconazole) were then introduced into the wells. The plates were left on the bench for $45 \mathrm{~min}$ and then incubated uprightly for $48 \mathrm{~h}$ at $26-28{ }^{\circ} \mathrm{C}$ to allow the extracts to diffuse properly into the agar [13].

\subsubsection{Minimum inhibitory concentration (MIC)}

A ten-fold dilution of each extract concentration (prepared in Sect. 2.2.2) was made by introducing a $2 \mathrm{~mL}$ portion of each into $18 \mathrm{~mL}$ nutrient agar at $45-50{ }^{\circ} \mathrm{C}$, giving rise to a new range of extract concentrations between $0.625-20 \mathrm{mg} / \mathrm{mL}$. The mixture was then poured aseptically into sterile plates and allowed to solidify. The organisms were streaked on the plates at different concentrations to determine the minimum concentration that would inhibit the growth of the organisms. The bacterial plates were incubated at $37{ }^{\circ} \mathrm{C}$ for $24 \mathrm{~h}$, while the incubation of the fungal plates was at $26{ }^{\circ} \mathrm{C}-28{ }^{\circ} \mathrm{C}$ for $48 \mathrm{~h}$. After incubation, the plates were observed for the growth of the microorganisms [13].

\section{Gas chromatography-mass spectroscopic (GC- MS) analysis}

An Agilent 7890 gas chromatograph equipped with a Chrompack CP-Wax 52 CB capillary column $(30 \mathrm{~m}$ length, internal diameter of $0.32 \mathrm{~mm}, 0.25 \mu \mathrm{m}$ film thickness) was used to separate the sample components. The gas chromatograph was connected to a mass selective detector operating in electron impact mode at $70 \mathrm{eV}$. A $1.0 \mu \mathrm{L}$ of the diluted sample was injected at $250^{\circ} \mathrm{C}$, in the splitless mode. Helium, flowing at the rate of $5 \mathrm{~mL} / \mathrm{min}$, was used as the carrier gas. The inlet pressure was 12.936 p.s.i. The column oven temperature was raised slowly (at a rate of $8^{\circ} \mathrm{C} / \mathrm{min}$ ) from $50^{\circ} \mathrm{C}$ to $240^{\circ} \mathrm{C}$, with a final hold time of $5 \mathrm{~min}$.

The sample constituents were identified by matching their mass spectra with the National Institute of Standards and Technology (NIST) Mass Spectral Library on the GC-MS database (NIST 14L). A similarity factor of $\geq 95 \%$ was used as a criterion for acceptance.

\section{Results}

Table 1 shows the zones of inhibition obtained when the extracts were screened for activity against the bacteria used in the study. The best activities against the

Table 1 In vitro antibacterial activity of /cacina trichantha leaves Extracts

\begin{tabular}{|c|c|c|c|c|c|c|c|}
\hline \multirow[t]{2}{*}{ Extracts } & \multicolumn{7}{|c|}{ Microorganism/zone of inhibition $(\mathrm{mm}) \pm \mathrm{SD}$} \\
\hline & Conc. (mg/ml) & $\begin{array}{l}\text { Staphylococcus } \\
\text { aureus }\end{array}$ & Escherichia coli & Bacillus subtilis & $\begin{array}{l}\text { Pseudomonas } \\
\text { aeruginosa }\end{array}$ & Salmonella typhi & Klebsiella pneumonia \\
\hline \multirow[t]{6}{*}{ ICLHE } & 200 & $28.0 \pm 0.82^{\mathrm{a}}$ & $23.7 \pm 0.47^{\mathrm{a}}$ & $24.6 \pm 0.94^{\mathrm{a}}$ & $19.7 \pm 0.47^{\mathrm{a}}$ & $18.0 \pm 0.82^{\mathrm{a}}$ & $15.7 \pm 0.47^{\mathrm{a}}$ \\
\hline & 100 & $24.0 \pm 0.82^{b}$ & $22.3 \pm 0.47^{b}$ & $19.7 \pm 0.47^{b}$ & $18.0 \pm 0.82^{b}$ & $16.7 \pm 0.94^{\mathrm{a}}$ & $13.7 \pm 0.47^{b}$ \\
\hline & 50 & $22.0 \pm 0.47^{c}$ & $17.7 \pm 0.47^{c}$ & $18.0 \pm 0.82^{c}$ & $14.7 \pm 0.47^{c}$ & $14.7 \pm 0.94^{\mathrm{a}}$ & $12.0 \pm 0.82^{c}$ \\
\hline & 25 & $17.5 \pm 0.47^{d}$ & $16.0 \pm 0.82^{d}$ & $13.6 \pm 0.47^{d}$ & $12.7 \pm 0.47^{d}$ & $11.7 \pm 0.47^{b}$ & $9.0 \pm 0.47^{d}$ \\
\hline & 12.5 & $14.6 \pm 0.47^{e}$ & $13.6 \pm 0.47^{e}$ & $11.3 \pm 0.47^{\mathrm{e}}$ & $10.3 \pm 0.47^{e}$ & $11.0 \pm 0.82^{b}$ & - \\
\hline & 6.25 & $12.0 \pm 0.82^{\mathrm{e}}$ & $11.0 \pm 0.82^{e}$ & $10.0 \pm 0.82^{e}$ & - & - & - \\
\hline \multirow[t]{6}{*}{ ICLEE } & 200 & $18.7 \pm 0.94^{\mathrm{a}}$ & $15.0 \pm 1.41^{\mathrm{a}}$ & $13.3 \pm 0.94^{\mathrm{a}}$ & $14.0 \pm 0.82^{\mathrm{a}}$ & $14.0 \pm 0.82^{a}$ & $14.0 \pm 0.82^{a}$ \\
\hline & 100 & $13.7 \pm 0.94^{b}$ & $13.3 \pm 0.47^{a}$ & $13.0 \pm 0.82^{\mathrm{a}}$ & $12.7 \pm 0.94^{\mathrm{a}}$ & $11.3 \pm 0.94^{b}$ & $11.3 \pm 0.47^{b}$ \\
\hline & 50 & $12.3 \pm 0.94^{b}$ & $11.7 \pm 0.47^{b}$ & $9.3 \pm 0.94^{b}$ & $9.7 \pm 0.47^{b}$ & $9.7 \pm 0.47^{b}$ & $9.7 \pm 0.47^{c}$ \\
\hline & 25 & $10.0 \pm 0.82^{c}$ & $10.3 \pm 0.47^{c}$ & - & - & - & - \\
\hline & 12.5 & - & - & - & - & - & - \\
\hline & 6.25 & - & - & - & - & - & - \\
\hline \multirow[t]{6}{*}{ ICLME } & 200 & $19.7 \pm 0.47^{\mathrm{a}}$ & $17.3 \pm 0.94^{\mathrm{a}}$ & $15.0 \pm 1.41^{\mathrm{a}}$ & $16.3 \pm 0.47^{\mathrm{a}}$ & $15.3 \pm 0.94^{\mathrm{a}}$ & $16.0 \pm 0.82^{\mathrm{a}}$ \\
\hline & 100 & $17.0 \pm 0.82^{b}$ & $16.3 \pm 0.47^{a}$ & $14.0 \pm 0.82^{\mathrm{a}}$ & $14.0 \pm 0.82^{b}$ & $14.0 \pm 0.82^{\mathrm{a}}$ & $13.0 \pm 0.82^{b}$ \\
\hline & 50 & $13.7 \pm 0.47^{c}$ & $14.0 \pm 0.82^{b}$ & $11.3 \pm 0.94^{b}$ & $11.3 \pm 0.94^{c}$ & $11.7 \pm 0.47^{b}$ & $11.3 \pm 0.47^{c}$ \\
\hline & 25 & $10.7 \pm 0.94^{d}$ & $13.3 \pm 0.94^{b}$ & $10.0 \pm 0.82^{b}$ & $10.7 \pm 0.94^{c}$ & $10.7 \pm 0.94^{b}$ & $9.7 \pm 0.47^{d}$ \\
\hline & 12.5 & - & $9.3 \pm 0.94^{c}$ & - & - & - & - \\
\hline & 6.25 & - & - & - & - & - & - \\
\hline Control & -ve & - & - & - & - & - & - \\
\hline Gentamicin & 10 & 40 & 38 & 38 & 38 & 38 & 40 \\
\hline
\end{tabular}


organisms were obtained at $200 \mathrm{mg} / \mathrm{mL}$. At this concentration, the hexane extract, ICLHE, showed inhibition zones ranging between $15.7 \pm 0.47 \mathrm{~mm}$ (against $K$. pneumoniae) and $28.0 \pm 0.82 \mathrm{~mm}$ (against $S$. aureus). Similarly, at $200 \mathrm{mg} / \mathrm{mL}$, zones of inhibition ranging between $14.0 \pm 0.82 \mathrm{~mm}$ (against $P$. aeruginosa, $S$. typhi, and K. pneumoniae) and $18.7 \pm 0.94 \mathrm{~mm}$ (against $S$. aureus) were obtained for the ethyl acetate extract. The values obtained ranged between $15.0 \pm 1.41 \mathrm{~mm}$ (against B. subtilis) and $19.7 \pm 0.47 \mathrm{~mm}$ (against $S$. aureus) at $200 \mathrm{mg} / \mathrm{mL}$ for the methanol extract. For all the extracts, the zones of inhibition increased with the extract concentration. The methanol and ethyl acetate extracts showed poor or no activity at concentrations of 6.25 and $12.5 \mathrm{mg} / \mathrm{mL}$. None of the extracts showed activity as high as that of the standard drug, Gentamicin.

Table 2 shows the results of the antifungal assay. The best activities were obtained at $200 \mathrm{mg} / \mathrm{mL}$. At this concentration, the hexane extract (ICLHE) showed zones of inhibition ranging between $15.7 \pm 0.47 \mathrm{~mm}$ (against Aspergillus niger) and $18.0 \pm 0.82 \mathrm{~mm}$ (against C. albicans). The ethyl acetate and methanol extracts (ICLEE and ICLME) showed no activity against $P$. notatum and $R$. stolonifer at all the extract concentrations. While activity increased with the concentration of the extracts, none of the extracts showed activity against the test fungi at 6.25 and $12.5 \mathrm{mg} / \mathrm{mL}$. The zones of inhibition obtained for the standard drug, Tioconazole, are higher than those of the extracts.

Table 2 In vitro antifungal activity of Icacina trichantha leaves extracts

\begin{tabular}{|c|c|c|c|c|c|}
\hline \multirow[t]{2}{*}{ Extracts } & \multicolumn{5}{|c|}{ Microorganism/zone of inhibition (mm) } \\
\hline & Conc. (mg/ml) & Candida albicans & Aspergillus niger & Penicillium notatum & Rhizopus stolonifer \\
\hline \multirow[t]{6}{*}{ ICLHE } & 200 & $18.0 \pm 0.82^{\mathrm{a}}$ & $15.7 \pm 0.47^{\mathrm{a}}$ & $18.0 \pm 0.82^{\mathrm{a}}$ & $16.3 \pm 0.47^{\mathrm{a}}$ \\
\hline & 100 & $15.3 \pm 0.94^{b}$ & $13.3 \pm 0.94^{b}$ & $13.7 \pm 0.47^{b}$ & $14.0 \pm 0.82^{b}$ \\
\hline & 50 & $13.3 \pm 0.94^{b}$ & $11.7 \pm 0.47^{b}$ & $11.7 \pm 0.47^{c}$ & $11.3 \pm 0.94^{c}$ \\
\hline & 25 & $10.3 \pm 0.47^{c}$ & $9.3 \pm 0.94^{c}$ & $9.3 \pm 0.94^{d}$ & $10.3 \pm 0.47^{c}$ \\
\hline & 12.5 & - & - & - & - \\
\hline & 6.25 & - & - & - & - \\
\hline \multirow[t]{6}{*}{ ICLEE } & 200 & $13.3 \pm 0.47^{a}$ & $14.0 \pm 0.82^{\mathrm{a}}$ & - & - \\
\hline & 100 & $12.6 \pm 0.47^{a}$ & $11.3 \pm 0.47^{b}$ & - & - \\
\hline & 50 & $9.7 \pm 0.47^{b}$ & $9.3 \pm 0.47^{c}$ & - & - \\
\hline & 25 & - & - & - & - \\
\hline & 12.5 & - & - & - & - \\
\hline & 6.25 & - & - & - & - \\
\hline \multirow[t]{6}{*}{ ICLME } & 200 & $16.0 \pm 0.82^{\mathrm{a}}$ & $15.7 \pm 0.47^{\mathrm{a}}$ & - & - \\
\hline & 100 & $13.3 \pm 0.94^{b}$ & $14.0 \pm 0.82^{b}$ & - & - \\
\hline & 50 & $11.7 \pm 0.47^{b}$ & $12.0 \pm 0.82^{c}$ & - & - \\
\hline & 25 & $9.7 \pm 0.47^{c}$ & $10.7 \pm 0.47^{c}$ & - & - \\
\hline & 12.5 & - & - & - & - \\
\hline & 6.25 & - & - & - & - \\
\hline Control & -ve & - & - & - & - \\
\hline Tioconazole & $70 \%$ & 28 & 26 & 26 & 28 \\
\hline
\end{tabular}

ICLHE-Hexane Extract of I. trichantha leaves; ICLEE-Ethylacetate Extract of I. trichantha leaves; ICLME-Methanol Extract I. trichantha leaves; - No Activity; concentrations with different superscripts are significantly different for each extract $(p<0.05)$

Table 3 Minimum inhibitory concentration of I. trichantha extracts

\begin{tabular}{|c|c|c|c|c|c|c|c|c|c|c|}
\hline \multirow[t]{2}{*}{ Extracts } & \multicolumn{10}{|c|}{ Minimum inhibitory concentration $(\mathrm{mg} / \mathrm{mL})$} \\
\hline & $\overline{S A}$ & EC & BS & PSA & ST & KP & CA & AN & PN & RS \\
\hline ICLHE & 2.50 & 2.50 & 2.50 & 5.00 & 5.00 & 10.00 & 5.00 & 10.00 & 10.00 & 10.00 \\
\hline ICLEE & 10.00 & 10.00 & 20.00 & 20.00 & 20.00 & 20.00 & 20.00 & 20.00 & 20.00 & 20.00 \\
\hline ICLME & 10.00 & 10.00 & 10.00 & 10.00 & 10.00 & 10.00 & 20.00 & 20.00 & 20.00 & 20.00 \\
\hline
\end{tabular}


The minimum inhibitory concentrations (MIC) of the extracts are shown in Table 3. The hexane extract (ICLHE) had the best activity against S. aureus, E. coli, and B. subtilis (MIC values of $2.50 \mathrm{mg} / \mathrm{mL}$ ). Moderate activity was observed against $P$. aeruginosa and $S$. typhi (MIC values of $5.00 \mathrm{mg} / \mathrm{mL}$ ). The least antimicrobial activity of the extract was observed against $K$. pneumoniae, $A$. niger, $P$. notatum, and $R$. stolonifer (MIC values of $10.00 \mathrm{mg} / \mathrm{mL}$ ). MIC values obtained against the organisms generally ranged between 10 and $20 \mathrm{mg} / \mathrm{mL}$ for the ethyl acetate (ICLEE) and methanol (ICLME) extracts.

The hexane extract possessed the best antimicrobial activity and was subjected to GC-MS analysis to identify the likely compounds responsible for the observed properties. To ensure accurate characterization of the compounds eluted from the column, only compounds with mass spectra having up to $95 \%$ similarity to those in the NIST library were reported. With this approach, only constituents corresponding to a total peak area of $44.71 \%$ were identified. The compounds successfully characterized are 2(4H)-Benzofuranone,5,6,7,7a-tetrahydro-4,4,7a-trimethyl- (1), n-Hexadecanoic acid (2), n-Hexadecanoic acid, ethyl ester (3), dl-alpha-Tocopherol (4), 4,8,12,16-tetramethylheptadecan-4-olide (5), Cholest-5-ene, 3-methoxy-(3-Beta)- (6), Stigmasterol (7), 2,6,10,14,18,22-Tetracosahexaene, 2,6,10,15,19,23-hexamethyl-, (all E) (8), Heptacosane, 1-chloro- (9) and $\beta$-Sitosterol (10). The structures of these compounds are shown in Fig. 1. The retention time and percentage composition of each identified compound in the hexane extract of the plant's leaves are shown in Table 4.

\section{Discussion}

The solvents used for extraction (in the current study) are of varying polarity (hexane is a non-polar solvent, ethyl acetate is moderately polar while methanol is polar). Since solvents dissolve compounds based on their polarity, this extraction protocol ensures that the compounds in the leaves are separated into non-polar (hexane), medium polar (ethyl acetate), and polar (methanol) compounds. Results obtained from the current study showed that at the same concentrations, the three extracts under investigation showed different activities against the test organisms. Differences in solvent polarities have been reported to account for differences in solubility of active plant principles, and hence, variations in the degree of activity of the extracts [14].

Results from a previous study showed that the methanol extract of the leaves of $I$. trichantha had zones of inhibition of $19.00 \pm 0.58 \mathrm{~mm}, 15.00 \pm 0.58 \mathrm{~mm}$, $25.00 \pm 0.58 \mathrm{~mm}, 21.00 \pm 0.58 \mathrm{~mm}, 4.00 \pm 0.58 \mathrm{~mm}$, and $7.00 \pm 0.58 \mathrm{~mm}$ against $S$. aureus, B. subtilis, P. aeruginosa, E. coli, A. niger, and C. albicans, respectively, at $20 \mathrm{mg} / \mathrm{mL}$ [6]. These results vary widely from those obtained for the same extract at a very similar concentration $(25 \mathrm{mg} / \mathrm{mL})$ against the same organisms in the current study (Table 1). The differences obtained could have resulted from the differences in the extraction protocols adopted. In the current study, a preliminary solventbased fractionation of the compounds present in the leaves of the plant was carried out before antimicrobial testing while in the previous study, a direct extraction using methanol was carried out. The solvent-based fractionation approach (employed in this study) simplifies the process of isolation and characterization of potential bioactive compounds from a sample by narrowing down on the number of compounds likely responsible for an observed activity. While the methanol extract in the current study showed some antimicrobial activity, the results obtained indicated that the most potent compounds responsible for the observed activity mostly reside in the hexane extract.

Generally, the zones of inhibition of the microorganisms increased with the increasing concentration of the extracts. Previous studies have reported similar results. For example, the zones of inhibition of methanol extract of flowers of Nelumbium speciosum against different microorganisms increased with extract concentration [15]. In addition, the results showed that the extracts, at the same concentrations, showed different activities against the microorganisms. The inhibition zone of an extract against an organism depends on the initial population density of the organism, and the nature and diffusion rate of the antimicrobial agent $[16,17]$.

Of the three extracts, the hexane fraction had the best activity against all the test micro-organisms. It even demonstrated moderate activity against gram-negative bacteria (E.coli, S. typhi, and P. aeruginosa). Gram-negative bacteria are generally more resistant to antibiotics than gram-positive bacteria. Gram-negative bacteria possess an outer membrane which is an asymmetric bilayer of lipopolysaccharides (LPS) and phospholipids, into which are fitted nonspecific porins and specific uptake channels. The LPS-containing bilayers are rigid and slow down passive diffusion of hydrophobic compounds while the narrow pores limit by size the penetration of hydrophilic drugs [18-20]. This extract probably contains compounds with the ability to overcome this barrier.

On comparing the MIC results (Table 3) with Tables 1 and 2, some discrepancies were observed. For example, when the MIC values obtained for ICLEE against $S$. aureus and E. coli was $10 \mathrm{mg} / \mathrm{ml}$ (Table 3), it is expected that some microbial growth would occur at $12.5 \mathrm{mg} / \mathrm{ml}$. Similarly, some microbial growth should be observed at $25 \mathrm{mg} / \mathrm{ml}$ (Table 1), when the MIC of the extract (ICLEE) was $20 \mathrm{mg} / \mathrm{ml}$ for $B$. subtilis, $P$. aeruginosa, 
<smiles>CC1(C)CCCC2(C)OC(=O)C=C12</smiles>

1<smiles>CCCCCCCCCCCCCCCC(=O)OCC</smiles>

3<smiles>CC(C)CCCC(C)CCCC(C)CCCC1(C)CCC(=O)O1</smiles>

5<smiles>CCC(/C=C/C(C)C1CCC2C3CC=C4CC(O)CCC4(C)C3CCC12C)C(C)C</smiles>

7

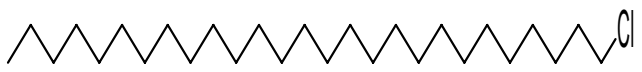

9<smiles>CCCCCCCCCCCCCCCC(=O)O</smiles>

2
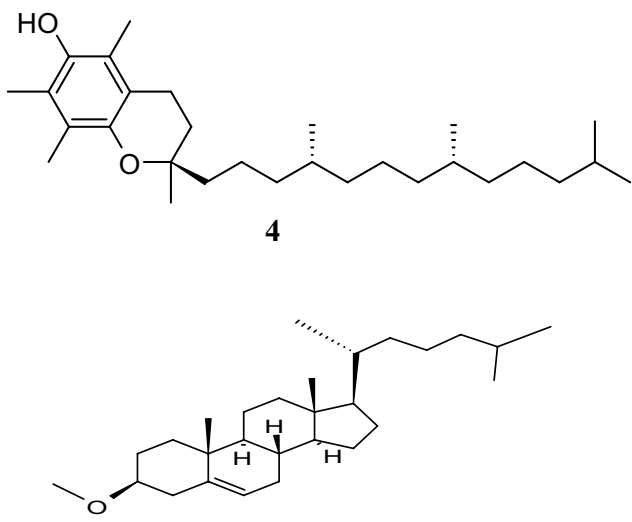

6<smiles>CC(C)=CCC/C(C)=C/CC/C(C)=C/CC/C=C(\C)C/C=C(\C)CCC=C(C)C</smiles>

Fig. 1 Structures of compounds identified in ICLHE by GC-MS

S. typhi, and K. pneumonia. The MIC values reported in Table 3 are single measurements, whereas those in Tables 1 and 2 are averages of triplicate measurements within limits of experimental error. In reporting the zones of inhibition of the microorganisms (Table 1) at the indicated concentrations (12.5 and $25 \mathrm{mg} / \mathrm{ml})$, it is possible that while some very minimal microbial growth was discernable on a plate, none existed on the two others, and the average of the values is approximately zero. This may be responsible for the apparent discrepancies observed.
The compounds detected in the hexane extract of the leaves of $I$. trichantha obtained in the current study (Table 4) differ significantly from the results obtained from the GCMS analysis of the same extract previously reported in the literature [11]. The literature report identified the compounds present in the extract as 3,3-dimethyl-2-hexanone, Undecane, Palmitic acid, 5-octadecenoic acid methyl ester, Stearolic acid, Stearic acid, 9,12-octadecadienoic acid, 9,17-octadecadienal, and Eicosanoic acid. This may be due to various factors. Apart from biochemical factors inherent within individual 
Table 4 Characterized chemical constituents of the n-hexane extract of leaves of I. trichantha

\begin{tabular}{|c|c|c|c|}
\hline Rt (min) & Compound & Similarity index & $\begin{array}{l}\text { Relative } \\
\text { composition (\% } \\
\text { area) }\end{array}$ \\
\hline 12.028 & 2(4H)-Benzofuranone,5,6,7,7a-tetrahydro-4,4,7a-trimethyl- & 96 & 0.66 \\
\hline 17.034 & n-Hexadecanoic acid & 96 & 5.28 \\
\hline 17.320 & n-Hexadecanoic acid, ethyl ester & 96 & \\
\hline 20.467 & dl-alpha-Tocopherol/Vitamin E & 96 & 7.98 \\
\hline 20.759 & 4,8,12,16-tetramethylheptadecan-4-olide & 96 & 0.90 \\
\hline 24.673 & Cholest-5-ene, 3-methoxy-(3-Beta)- & 95 & 0.42 \\
\hline 27.242 & Stigmasterol & 99 & 5.86 \\
\hline 29.308 & $\begin{array}{l}\text { 2,6,10,14,18,22-Tetracosahexaene, 2,6,10,15,19,23-hexamethyl-, } \\
\text { (all E) }\end{array}$ & 99 & 13.55 \\
\hline 31.745 & Heptacosane, 1-chloro- & 97 & 1.36 \\
\hline 32.077 & $\beta$-sitosterol & 99 & 8.70 \\
\hline
\end{tabular}

plant species, several external factors such as geographical location, climate, nature of soil, season, and growth conditions have a major influence on plants' phytoconstituents [21]. For example, phytochemicals in different plants possessing anticancer properties have been known to change quantitatively with seasons [22, 23]. Similarly, new active compounds have been reported from different plant parts collected at different times or from different locations [21].

Plants contain compounds that are responsible for their bioactivities. Ten compounds were identified successfully in the hexane extract of leaves of I. trichantha; however, only two of these compounds (Stigmasterol (7) and $\beta$-sitosterol) have been reported (in literature) to possess antimicrobial properties. $\beta$-sitosterol (10) has been reported to show activity against $S$. aureus, $B$. subtilis, and $K$. pneumoniae with zones of inhibition of $27 \mathrm{~mm}, 34 \mathrm{~mm}$ and, $26 \mathrm{~mm}$, respectively. It also showed a minimum inhibitory concentration of 25,12 , and $25 \mu \mathrm{g} /$ $\mathrm{mL}$, respectively, against these organisms. However, it showed no activity against $E$. coli, $P$ aeruginosa, and $C$. albicans [24]. Stigmasterol (7) (at $100 \mu \mathrm{g} / \mathrm{mL}$ ) showed $29 \mathrm{~mm}$ as the zone of inhibition against $S$. aureus, $24 \mathrm{~mm}$ against E. coli, and $25 \mathrm{~mm}$ against $C$. albicans [25]. Stigmasterol had zones of inhibition of $21 \mathrm{~mm}$ against $S$. aureus, $24 \mathrm{~mm}$ against $B$. subtilis, $21 \mathrm{~mm}$ against $E$. coli, and $21 \mathrm{~mm}$ against $C$. albicans at $50 \mu \mathrm{g} / \mathrm{mL}$ [26]. These literature reports indicate that the compounds, Stigmasterol and $\beta$-sitosterol, possess far higher antimicrobial activities (against the indicated organisms) than the crude hexane extract of $I$. trichantha as shown by the results obtained from the current study. This may be due to the presence of both compounds in small quantities in the crude hexane extract (the peak areas for Stigmasterol and $\beta$-sitosterol are $5.86 \%$ and $8.70 \%$, respectively).
In a previous study, Stigmasterol isolated from the stem bark of $N$. macrophylla displayed an improved inhibitory effect and lower MIC value when compared to the extract [27]. The antibacterial activity of steroids is attributable to their ability to inhibit 'sortase' a participant in pathways involving secretion and anchoring of cell wall proteins [28]. Membrane disruption could be one of the possible mechanisms of the action of sterols on microorganisms [29]. However, the antimicrobial properties of the hexane extract may not be entirely due to these two compounds. As noted earlier, a large percentage of the peaks in ICLHE are unidentifiable (55.29\%). The compounds corresponding to these peaks could have made significant contributions to the antimicrobial action of the extract. Furthermore, since GC-MS is unsuitable for analyzing non-volatile plant constituents, these compounds might not have been detected (though they may possess significant antimicrobial activities).

\section{Conclusions}

The extracts under investigation were not as active as the standard drugs, Gentamicin, and Tioconazole against the test organisms. The hexane extract showed some activity against the test organisms, thereby providing some basis for the plant's use in traditional medicine for treating skin infections. Stigmasterol and $\beta$-Sitosterol are possible contributors to the antimicrobial activity of the extract (since their antimicrobial activities are well documented in the literature). However, the observed activities may be due to other compounds which could not be identified or detected using GCMS (because they are non-volatile). Further studies are needed to isolate and characterize the compounds responsible for the antimicrobial activity of the extract. 


\begin{abstract}
Abbreviations
ICLHE: I. trichantha Leaves hexane extract; ICLEE: I. trichantha Leaves ethylacetate extract; ICLME: I. trichantha Leaves methanol extract; TIOC: Tioconazole (70\%); GENT: Gentamicin; SA: Staphylococcus aureus; EC: Escherichia coli; BS: Bacillus subtilis; PSA: Pseudomonas aeruginosa; ST: Salmonella typhi; KP: Klebsiella pneumoniae; CA: Candida albicans; AS: Aspergillus niger; PN: Penicillium notatum; RH: Rhizopus stolonifer; NA: No activity; NT: Not tested.
\end{abstract}

\section{Acknowledgements}

Not applicable.

\section{Authors' contributions}

TTA, LL, MO and BO designed the study. TT carried out the experimental studies. All authors participated in writing the manuscript. All authors read and approved the final manuscript.

\section{Funding}

Not applicable.

\section{Availability of data and materials}

All data generated or analyzed during this study are included in this published article.

\section{Declarations}

Ethics approval and consent to participate

Not applicable.

\section{Consent for publication}

Not applicable.

\section{Competing interests}

The authors declare that they have no competing interests.

\section{Author details}

'Department of Chemistry, Federal University Otuoke, Otuoke, Bayelsa State, Nigeria. ${ }^{2}$ Department of Chemistry, Federal University of Technology Akure, Akure, Ondo State, Nigeria. ${ }^{3}$ Department of Biochemistry, Federal University of Technology Akure, Akure, Ondo State, Nigeria.

Received: 31 March 2021 Accepted: 4 November 2021

Published online: 18 November 2021

\section{References}

1. Theuretzbacher U, Mouton JW (2011) Update on antibacterial and antifungal drugs: Can we master the resistance crisis? Curr Opin Pharmacol 11:429-432

2. Lowy F (2003) Antimicrobial resistance: the example of Staphylococcus aureus. J Clin Investig 111:1265-1273

3. Munita JM, Arias CA (2016) Mechanisms of antibiotic resistance. Microbiol Spectr. https://doi.org/10.1128/microbiolspec.VMBF-0016-2015

4. Cowan MM (1999) Plant products as antimicrobial agents. Clin Microbiol Rev 12(4):564-582

5. World Health Organization. Traditional Medicine Strategy. Available via https://www.who.int/medicines/publications/traditionalpolicy/en/. Accessed 30 March 2021

6. Timothy $\mathrm{O}$, Idu M (2011) Preliminary and in vitro antimicrobial properties of aqueous and methanol extracts of Icacina trichantha Oliv. Leaf Int J Med Arom Plants 1(3):184-188

7. Asuzu IU, Abubakar II (1995) The effects of Icacina trichantha tuber extract on the nervous system. Phytother Res 9:21-25. https://doi.org/10.1002/ ptr.2650090106

8. Onakpa MM, Asuzu IU (2013) Histological changes and anti-diabetic activities of Icacina trichantha tuber extract in beta-cells of alloxaninduced diabetic rats. Asian Pac J Trop Biomed 3:628-633. https://doi.org/ 10.1016/S2221-1691(13)60127-6

9. Asuzu IU, Egwu OK (1998) Search for the centrally active component of Icacina trichantha tuber. Phytomedicine 5:35-39
10. Zhao M, Onakpa MM, Chen W, Santarsiero BD, Swanson SM, Burdette JE, Asuzu IU, Che C (2015) 17-Norpimaranes and (9 $\beta \mathrm{H})$-17-Norpimaranes from the Tuber of /cacina trichantha. J Nat Prod 78(4):789-796

11. Otun KO, Onikosi DB, Ajiboye AA, Jimoh AA (2015) Chemical composition, antioxidant and antimicrobial potentials of Icacina trichantha Oliv. Leaf Extracts Nat Prod Chem Res 3:188. https://doi.org/10.4172/23296836.1000188

12. Shagal MH, Kubmarawa D (2013) Antimicrobial and phytochemical screening of Icacina trichantha. Am J Biomed Life Sci 1(2):37-40

13. Adeniyi BA, Izuka KC, Odumosu B, Aiyelaagbe $O O$ (2013) Antibacterial and antifungal activities of methanol extracts of Desmodium adscendens root and Bombax buonopozense leaves. Int J Biol Chem Sci 7(1):185-194. https://doi.org/10.4314/ijbcs.v7i1.15

14. Ngo TV, Scarlett CJ, Bowyer M, Ngo PD, Vuong QV (2017) Impact of different extraction solvents on bioactive compounds and antioxidant capacity from the root of Salacia chinensis L. J Food Qual 1:1-8. https:// doi.org/10.1155/2017/9305047

15. Bashir S, Sial RN, Ashraf MU, Mushtaq MN, Adnan MA, Erum A (2018) Phytochemical analysis and antimicrobial activity of aqueous and methanolic extracts of the flowers of Nelumbium speciosum. Pak J Pharm Sci 31(6):2429-2434

16. Hugo WB, Russel AD (2007) Pharmaceutical microbiology (7th edn) Blackwell Scientific Publication, London, p 313

17. Pelczar MJ; Chan JR; Krieg ECS (2002) General Microbiology Text (5th edn) McGraw-Hill: USA; 469-509

18. Zgurskaya HI, Lopez CA, Gnanakaran S (2015) Permeability barrier of gram-negative cell envelopes and approaches to bypass it. ACS Infect Dis 1(11):512-522

19. Denyer SP, Maillard JY (2002) Cellular impermeability and uptake of biocides and antibiotics in gram-negative bacteria. J Appl Microbiol 92(1):35S-45S

20. Nikaido H (1998) Antibiotic resistance caused by gram-negative multidrug efflux pumps. Clin Infect Dis 27(1):S32-41

21. Ullah MO, Haque M, Urmi KF, Zulfiker AH, Anita ES, Begum M, Hamid K (2013) Antibacterial activity and brine shrimp lethality bioassay of methanolic extracts of fourteen different edible vegetables from Bangladesh. Asian Pac J Trop. Biomed 1-7

22. Muraina IA, Adaudi AO, Mamman M, Kazeem HM, Eloff JN (2008) Effects of geographical location on the yield and bioactivity of Anoigeissus leiocarpus. J Pharm Bioresour 5(2):68-72

23. Mukherjee S, Ghosh B, Jha TB, Jha S (2002) Variation in content of taxol and related taxanes in Eastern Himalayan populations of Taxus wallichiana. Planta Med 68:757-759

24. Elgorashi EE, Taylor JLS, Maes A, De Kimpe N, Van Staden J, Verschaeve L (2002) The use of plants in traditional medicine: potential genotoxic risks. S Afr J Bot 68:408-410

25. Odibaa JO, Musaa AM, Hassana HS, Yahayaa SM, Okolo El (2014) Antimicrobial activity of isolated Stigmast5-en-3 $\beta$-ol ( $\beta$-Sitosterol) from Honeybee Propolis from North-Western, Nigeria. Int J Pharm Sci Res 5(12):908-918

26. Yusuf AJ, Abdullahi MI, Aleku GA, Ibrahim IAA, Alebiosu CO, Yahaya M, Adamu HW, Sanusi A, Mailafiya MM, Abubakar H (2018) Antimicrobial activity of Stigmasterol from the stem bark of Neocarya macrophylla. J Med Plants Econ Dev. 2(1):1-5. https://doi.org/10.4102/jomped.v2i1.38

27. Yinusa I, George NI, Shuaibu OA, Ayo RG (2014) Bioactivity of Stigmasterol isolated from the aerial part of Spillanthes acmella (Murr) on the selected microorganism. Int J Curr Microbiol App Sci 3(2):475-479

28. Kanokmedhakul K, Kanokmedhakul S, Phatchana R (2005) Biological activity of anthraquinones and triterpenoids from Prismatomeris fragrans. J Ethnopharmacol 100:284-288. https://doi.org/10.1016/j.jep.2005.03.018

29. Tamokou JD, Kuiate JR, Tene M, Nwemeguela TJK, Tane P (2011) The antimicrobial activities of extract and compounds isolated from Brillantais lamium. Iran J Med Sci 36(1):24-31

\section{Publisher's Note}

Springer Nature remains neutral with regard to jurisdictional claims in published maps and institutional affiliations. 